\title{
THE DIGITAL TECHNOLOGIES IN EDUCATION
}

\author{
GEORGE NICULESCU \\ “CONSTANTIN BRANCUŞI” UNIVERSITY OF TÂRGU-JIU \\ gniculesco@yahoo.com
}

\begin{abstract}
Education, education systems with their institutions and organizations are in crisis and deeply inadequate.

This article aims to identify the uses and effects of information and telecommunications technology (ICT) on education.

The adaptation of universities and teaching staff to technological innovations, in the context of changing the culture of our society is the main objective of this article.

The creation of a digital fluency laboratory model or a digital innovation laboratory represents an opportunity for developing the quality of education and a new challenge for educational institutions.

Also, we aim to develop educational content with innovative content through the use of digital technologies that promote quality learning experiences.

Keywords: digital technologies, model, university, labor market, laboratory, inadequacy.
\end{abstract}

\section{INTRODUCTION}

Education and education systems are deeply inadequate not only in Romania, but also in the EU and worldwide. Education with its systems must radically change.

The world of the future, for which we prepare students, will be completely different from the current one. In yesterday's and today's education uniformity, instruction, memorization, conformity predominate. It is necessary for tomorrow's education to enhance the imagination, creativity and inventiveness of the beneficiaries of educational services. Schools, colleges and universities must first prepare their teachers for change. They can become the vectors of change. It is necessary to adapt them to the changes of our society's culture in response to technological innovations. [1]

Online learning opportunities and the use of open educational resources and other technologies can reduce the costs associated with the materials needed for training and allow more efficient use of teacher time. Today, we can talk about blended learning that combines face-to-face learning opportunities with online learning opportunities. The degree to which online learning takes place and how it is integrated into the curriculum may vary by school. The strategy of combining online learning with face-to-face school instruction is useful to adapt the various learning styles of the learners and to allow each learner to study at their own pace. [2].

Online resources allow to revolutionize the educational system, not only because they are convenient and accessible, but because they allow the whole process of teaching and learning to become more interesting and adapted to the digital student. [9]. Thus, a learning customization is achieved. Today, students and teachers benefit from free online resources and paid online resources. Each student prefers different resources depending on the topics of interest and the learning style. [3].

\section{EDUCATION AND TECHNOLOGY}

Education and technology are becoming more and more natural.

The uses and effects of information and telecommunications technology (ICT) on education are identified. We believe that ICT has developed rapidly in recent years and has become a common tool in education. [4]. 
There are four main effects of ICT exposure and use on education.

a.Time spent on social networks

First, the use of the Internet during the courses. The impact of time spent on social networks can be measured. This has a negative impact on student outcomes. There is a directly proportional relationship between the time spent on social networks and its impact on school performance.

b. Internet searches

Time spent researching the internet in school to complete their homework. The use of the Internet for school research has a modest positive impact on school performance. [10].

To have a positive effect on their grades, students must devote significant time to their research on the Internet. Otherwise, Internet searches had no effect on student grades. Internet searches offer relative value only when you spend a lot of time on them, they bring a lot to the training of young students.

c. The age of access to ICT

Regarding the impact of the age of the first exposure to technology, access to technologies (for educational purposes) from the first years of childhood has a positive and significant impact on the school performance. Thus, the students who had access before 9 years to the ICT can have better results. compared to those who had access after this age,

One hypothesis that could explain this effect is the development of logical thinking, due to the contact with the programming and the use of different software programs.

The champions in this area are New Zealand and Denmark, where $90 \%$ of children have access to ICT before the age of 9.

d.Smartphone sites

Smartphones have been widespread since 2012. Assessing the impact on school performance of smartphone use in school is difficult to quantify. In general, the use of the smartphone has a negative effect. But the impact varies from country to country and it is not possible to establish a direct correlation between the time of use of the smartphone and its effects.

New technologies can be used for personal development and skills training. According to research conducted by the Center for Creative Leadership, only 10\% of the skills are developed in one class. About 20\% comes from developing relationships with colleagues and mentors, and $70 \%$ from experience comes from experimentation (often with the help of new technologies). [5].

If the new educational technologies are harmoniously integrated with the latest research in the fields of neuropsychology, cognitive psychology, sociology of cognition and motivation, a leap in pedagogy and learning can be achieved, thus opening the way to a new educational paradigm. [6].

\section{UNIVERSITIES AND THE INADEQUACY OF THE EDUCATION SYSTEM}

In today's highly dynamic, uncertain and volatile world, the education system fails to keep up, and universities cannot solve the problems needed to thrive in the future. New jobs are emerging for which the education system is not ready and is not in step with reality. Thus, jobs such as "drone operator", "virtual reality manufacturer" or "machine learning engineer" were not conceived 10 years ago. The pace of change is growing faster due to the unifying progress made by artificial intelligence, digitization and automation. [7]

Traditional universities cannot keep up with this rapidly evolving work future. Simple tradition cannot compete with the present. Without taking into account augmented reality, universities become a stumbling block to development. Universities must change the way they learn. They must evolve with major changes occurring at smaller time intervals. [11]. 
Annals of the „Constantin Brâncuşi” University of Târgu Jiu, Economy Series, Issue 6/2019

Today there is a great distance between the "university" and the "real world". Traditional universities have never been designed to train graduates to know how to pivot between work and learning at new jobs and to train their skills in this regard. [8].

The fourth industrial revolution causes a large reduction of roles, as they become redundant or automated. According to the Future Jobs Report of 2018, [17]. it is anticipated that 75 million jobs will be relocated by 2022 in 20 major economies. At the same time, technological advances and new ways of working could also create 133 million new roles, determined by the large-scale growth of new products and services that would enable people to work with machines and algorithms to meet the demands. of demographic and economic changes. changes.

The new type of university must focus on "learning on time".

A "learning on time" university is based on some very well-defined rules.

Thus, the most important aspect is for a university to create the ability to "learn how to learn", to learn quickly to allow the graduate to be flexible, to adapt quickly and to be innovative as the world changes. The new type of university allows graduates to reinvent themselves and remain permanently productive. The current education system measures success through the ability to store and transmit data and information. Reality does not require this from universities.

The new type of university promotes lifelong learning. During the faculty one learns during three or four years eight months, and four months working. Then, for the rest of the professional life, one month is learned and 11 months are worked. The new type of university offers continuous feedback, in real time, for the student to know his abilities and shortcomings. [12].

Last but not least, it is necessary to learn from several methods, not just from the university. According to the research conducted by the Center for Creative Leadership, only $10 \%$ of the skills are developed in the classroom, $20 \%$ come from the development relationships with colleagues and mentors, and $70 \%$ from their own experience.

I mean, you learn best by doing. The approach to action research methodology is effective. At a university of "early learning", performance is not evaluated through exams, but through concrete projects implemented and feedback from colleagues and managers.

Only online learning is lacking in our development relationships with colleagues and mentors, which are crucial to personal development.

To get in touch with reality, we need to "learn in time" in all disciplines - not just in technology - and in every stage of life. [15].

Organizations and managers who are brave enough and will break the convention and rethink learning are the ones who will thrive in the future tsunami of technological disruption.

Information and communication technologies (e-mail, internet, video conferencing) have created the alternative of e-learning. Information technology creates the possibility for higher education to be independent of the spatial-temporal context.

Models of distance learning are gaining ground, especially among non-traditional and nonconformist students, as well as among those who are doing concurrent studies and in parallel with their professional activity.

There are two main ways that focus on the importance of educational technology; first, online learning and, secondly, the impact on teaching, learning and administration. As technology continues to integrate and change the world in which we live and operate, higher education must also change over time, integrating educational technology that facilitates international higher education. This, however, can be a daunting task, with the multitude and diversity of educational technologies available. [13].

In order to cope with the future changes caused by new technologies, at least $54 \%$ of current employees will need to be retrained and upgraded by 2022. Universities need to get more involved in preparing human resources through intensive personal training. 
Annals of the „Constantin Brâncuşi” University of Târgu Jiu, Economy Series, Issue 6/2019

The beneficiaries of the educational services must be prepared for the new technologies that are constantly changing because the involvement of the "machine" will be increasing. Thus, the comparison between man-hours and machine-hours is projected in the following table[17].:

Table no. 1 Ratio of human-machine working hours, 2018 vs. 2022 (projected)

\begin{tabular}{|l|l|l|l|l|}
\hline ACTIVITIES & Human & $\begin{array}{l}\text { Machine } \\
\mathbf{2 0 1 8} \\
\mathbf{\%}\end{array}$ & $\begin{array}{l}\text { Human } \\
\text { Machine } \\
\mathbf{2 0 2 2} \\
\mathbf{\%}\end{array}$ \\
\hline Reasoning and decision-making & 81 & 19 & 82 & 28 \\
\hline Coordinating, developing, managing and advising & 81 & 19 & 81 & 29 \\
\hline Communicting and interacting & 77 & 23 & 69 & 31 \\
\hline Administering & & 28 & 56 & 44 \\
\hline Reforming physical and manual work activities & 69 & 31 & 56 & 44 \\
\hline $\begin{array}{l}\text { Identifying and evaluating job-relevant } \\
\text { information }\end{array}$ & 71 & 29 & 54 & 46 \\
\hline Performing complex and technical activities & 66 & 34 & 54 & 46 \\
\hline Looking for and receiving job-related information & 64 & 36 & 45 & 55 \\
\hline Informationand data processing & 53 & 47 & 38 & 62 \\
\hline
\end{tabular}

Source: Future of Jobs Survey 2018, World Economic Forum

\section{THE DIGITAL FLUENCY LABORATORY AND / OR THE DIGITAL INNOVATION LABORATORY}

To cope with the onslaught of new digital technologies, the need for a digital fluency and digital innovation laboratory is becoming more and more necessary at the university level.

The competence of "digital literacy" refers to the complex ability to master and use information technologies and / or the internet and includes as the most important components, such as: computer literacy, network literacy, information literacy and social media literacy, but more recently: literacy IoT (internet of things), "artificial intelligence" literacy, etc., as well as the more pragmatic and ubiquitous use of smart phones. [14]

The issue of "digital literacy" has become a thorny issue for anyone and not just for less developed countries and / or societies and / or communities. Trying to solve it starting from the "digital literacy" end is a cumbersome procedure, which takes time and the results are limited to becoming "mediocre consumers".

The correct and fast resolution can be done at the end of the output, namely the "digital fluency". This approach allows for fast and innovative digital literacy, using methodologies, techniques and tools such as "second-order orality", "artificial intelligence", "broadband", "grandparent collaboration", "augmented reality and / or virtual reality" and so on This approach aims at training "smart consumers" and then transforming some of them into "innovative creators of new content and / or intelligent, connected products and services".[16]

Through the "digital innovation" component, the laboratory aims to provide technical support to the other laboratories of the center in order to develop and make its own "digital products", such as MOOC and / or MOOP.

\section{CONCLUSION}


Annals of the „Constantin Brâncuşi” University of Târgu Jiu, Economy Series, Issue 6/2019

The rapid evolution of ICT allows us to identify trends in the use of technology and its effects on education.

The increasing influence and effectiveness of artificial intelligence, digitization and automation determines an ever faster pace for major changes.

Online resources allow a radical change of educational assistance because they allow the whole process of teaching and learning to become more interesting and adapted to the digital student. In this way, a personalization of learning is achieved.

We need a new type of learning institution to be designed for the 21st century. This type of institution has to focus on what is called "on time learning".

At a "learning on time" institution, performance is not evaluated through exams, but through projects actually implemented and through feedback from colleagues and managers.

As technology continues to integrate and change the world in which we live and operate, higher education must also change over time, integrating educational technology that facilitates international higher education.

It is necessary to adapt universities and teaching staff to technological innovations, in the context of changing the culture of our society.

If used efficiently, new technologies can be used for personal development and training of students and students.

\section{BIBLIOGRAPHY}

[1]. Altbach G. Philip, Center for International Higher Education, Boston College, 2013

[2]. Christensen M. Clayton, Eyring J. Henry The Innovative University: Changing the DNA of Higher Education from the Inside Out San Francisco, 2011

[3]. Marga Andrei, Die kulturelle Wende. Philosophische Konsequenzen der Transformation, University Press Cluj, 2004 edition).

[4]. Andrei Marga, Crisis and after the crisis, Eikon Publishing House, Cluj, 2010, (second

[5]. Rasfeld Margret, Spiegel Peter, EduAction. Wir machen Schule, Murrmann, Hamburg, 2012 2002;

[6]. Tomlinson, John, Globalization and Culture, Amarcord Publishing House, Timisoara,

[7]. Trout, Jack, Differentiate or Die: How to Survive the Present Age

competition, Brandbuilders Publishing, 2006;

[8]. Ulrich, Beck, What is globalization? Errors of globalism - answers to

globalization, Trei Publishing House, Bucharest, 2001;

[9]. Vlasceanu, Lazar, Sociology and modernity. Transitions to reflective modernity,

Polirom Publishing House, Iasi, 2007

[10]. Ainslee Janetta, Digitization Of Education In The 21st Century In Educational Technology, eLearning Industry, April 28, 2018

[11. Cojocaru v. Gh., Education Change and Managerial Change, Educational Management, Chisinau, 2018

[12]. Neagu Gabriela, Innovation in Education, Quality of Life Magazine, 2009.

[13].Pop Gabriela, Innovation and change in education, EDICT Magazine, Botosani, 2017

[14].Popescu Maria, Innovation Management, Transilvania University Publishing House, Brașov, 2016.

[15]. Swaniker Fred, How Learning Can Catch Up With Technological Change, 2019, https://fortune.com/2019/08/27/higher-education-interactive-learning/, accessed 22.10.2019 
Annals of the „Constantin Brâncuşi” University of Târgu Jiu, Economy Series, Issue 6/2019

[16].Williams Dean, Real Leadership - Helping People and Organizations Face Their Toughest

Challenges, Berrett-Koehler Publishers, 2005

[17]. XXX World Monetary Forum for the Future Jobs Report, 2018 